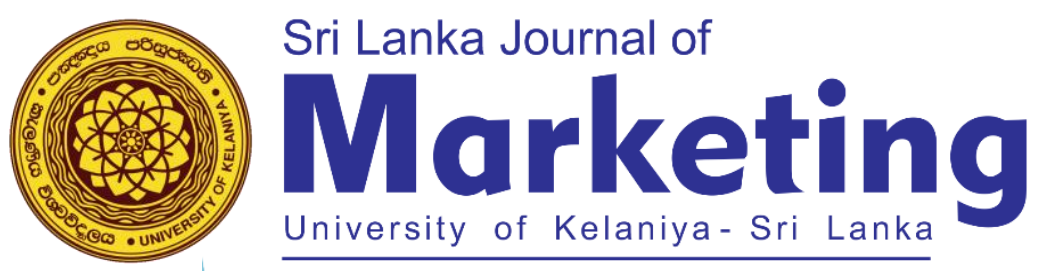

\title{
The Impact of Negative Brand Experience on Brand Avoidance with the Mediating Effect of Negative Emotions: Evidence from the Sri Lankan Mobile Telecommunication Sector
}

\author{
Amarasinghe, D.P. \\ University of Colombo, Sri Lanka \\ dilshiniamarasinghe7@gmail.com \\ Jayasinghe, J.A.S.C. \\ Senior Lecturer, University of Colombo, Sri Lanka \\ sarathj@mkt.cmb.ac.lk
}

\begin{abstract}
A knowledge gap existed in the light of available literature due to a lack of comprehensive understanding and conflicting viewpoints regarding negative brand experience and brand avoidance. This research aims to investigate the impact of negative brand experience on brand avoidance in the Sri Lankan mobile telecommunication industry. Further, it investigates the impact of negative brand experience on negative emotions, negative emotions on brand avoidance and examines the mediating effect of negative emotions in the relationship. This research is a positivistic study done using a questionnaire in selected urban areas based on a convenience sample of 120. A SEM model was used to analyze the data based on SPSS and Amos 23. The research bridges the theoretical gap that existed due to unawareness of simultaneous effects of negative brand experience and negative emotions on brand avoidance in the Sri Lankan context. Findings indicate that negative brand experience positively affects brand avoidance, while negative emotions also positively affect brand avoidance. Further, it realizes that negative brand experience has no significant effect on negative emotions. Finally, the research found that negative emotions have no mediating effect on the relationship between negative brand experience and brand avoidance.
\end{abstract}

Keywords: Brand Avoidance, Branding, Mobile Communications, Negative Brand Experience, Negative Emotions 


\section{INTRODUCTION}

Technological development, globalization, and competition can be identified as the main reasons for raising the usage of mobile telecommunication services among consumers. The estimates for 2017 show that the Asia Pacific region has the highest number of unique mobile subscribers. The Asia Pacific region is expected to add around 571 million unique mobile subscribers, representing two-third of new subscriber growth worldwide over the next four years ("Asia pacific region owned the largest unique mobile subscribers number 2017”, n. d.). In January 2021, there are 30.41 million mobile subscribers in Sri Lanka (Datareportal, 2021). Sri Lankan mobile space is shared by four operators. They are Bharti Airtel Lanka (Pvt) Ltd., Dialog Axiata PLC, Hutchshion Telecommunications Lanka (Pvt) Ltd., and Mobitel (Pvt) Ltd. (TRCSL, 2020).

There is huge competition among the service providers who have thousands of similar offerings, and they may miss satisfying their customer needs properly (Gunawardane, 2015). Consequently, these unsatisfied customers respond to brands negatively. Therefore, the negative side of the brand attitudes needs much attention. According to Khan (2018), the literature on this anti-consumption is not sufficiently explored. These include unmet expectations, negative past experiences, and deceptions which may cause brand avoidance. Brand avoidance has been defined by Lee et al. (2009). Accordingly, brand avoidance occurs when consumers deliberately reject a brand. When there are more negative brand experiences which consumers may face in mobile telecommunication services, brand avoidance could be a problem in a competitive mobile telecommunication market.

In the light of current literature, it is evident that researchers have done extensive research on the positive side of brand attitudes, but the studies on the negative sides are scant. According to some past studies, negative brand experiences could lead to brand avoidance (Khan, 2018). However, some other studies show customers may not avoid their service provider even if they have negative brand experiences with the service due to some switching costs such as sunk costs and losing current contact numbers (Kumaresh, 2009). Some more potential brand avoidance barriers include lack of alternatives, others' influence, inertia, and low product involvement (Lee et al., 2009, as cited in Kim et al., 2013). Aforesaid two conflicting views demand more comprehensive research in the relationship between negative brand experience and brand avoidance. Further, as Romani et al. $(2009 ; 2012)$ pointed out, the adverse brand performance triggers emotions. Brand avoidance behavior appears when negative emotions about brands become strong (Romani et al., 2012). According to Kavaliauské and Simanavičiūte (2015), emotions and brand avoidance still need further exploration. Surprisingly so far, simultaneous effects of negative brand experience and negative emotions on brand avoidance have been overlooked and neglected. 
Thus, this research mainly aims to identify whether negative brand experience impacts brand avoidance in the mobile telecommunication services industry of Sri Lanka. Further, the present study also aims to achieve three sub-objectives; to identify whether negative brand experience affects negative emotions, to find out whether negative emotions affect brand avoidance, and to investigate whether negative emotions mediate the relationship between negative brand experience and brand avoidance in the mobile telecommunication services industry of Sri Lanka.

The remainder of this paper begins with reviewing the literature and formulating research hypotheses. Then the conceptual model is presented, and the methodology is described. Thereafter, data analysis and the results are presented. Finally, a discussion will be carried out and, conclusions and recommendations will be followed.

\section{LITERATURE REVIEW}

\subsection{Brand Experience}

Brand experiences in a service branding context can occur through three elements: core service performance, service employee behavior, and the service escape (Grace \& O'Cass, 2004, as cited in Leung, 2016). In customers' experience with service encounters, core service performance is vital in customers' satisfaction and future behavior (Dimitriadis \& Koritos, 2014) or the basic motivation for the customer to get in touch with a service provider (Dimitriadis \& Koritos, 2014). Customers' intention to remain with a service provider is heavily determined by customer-contacted employee behavior (Kattara et al., 2008). Servicescape is a setting place where services are provided (Raisanen et al., 2014, as cited in Celik, 2019). It includes all physical factors which consumers encounter from their entry to stores to exit (Celik, 2019). Store service escape in the mobile telecommunication sector positively affects customers' behavioral intentions (Celik, 2019). As in the retail sector, consumers evaluate their experience with service escape (Kwon et al., 2015, as cited in Celik, 2019). Brand experiences are likely to influence customers' behavioral responses (Hussein, 2018). Emotional assessment regarding past experience can affect future behavior (Tosun et al., 2015). Direct experiences with service failures might lead to tremendous attitude change and be more likely to guide behavior (Mattila, 2004).

\subsection{Negative Brand Experience}

A negative brand experience occurs when consumers get their expectations unmet by the brand. If the consumers who experienced a brand's bad performance are not treated properly, they will be disappointed and, in the future, may avoid the product or the service entirely (Liu, 2019). Besides, these disappointments about not receiving the expected service performance may cause the frustration of customers. Previous negative experience with the product or service brand is associated with various adverse customer behavior outcomes (Zarantonello et al., 2018). Negative past experience was caused 
mainly by the failures or dissatisfaction towards a service (Hegner et al., 2017, as cited in Wu et al., 2018). These failures may arise due to poor performance of the service, inconvenience (hassle) associated with acquiring the service (Lee et al., 2009b). Further, in the absence of proper employee behavior, customers get negative experience, which causes a lack of employee-customer cooperation, which is a must for better service performance.

When consumers get a negative experience, they consider it more seriously compared to a positive experience (Kanouse, 1984). According to Kanouse (1972), in consumer behavior, it is described as negativity bias. The people with such negative experiences would share their undesirable ones and write on them more (Baumeister et al., 2001). When consumers plan to purchase, they think about a satisfactory brand and better performance. Negative feelings due to dissatisfaction occur when product performance cannot exceed the expectations of consumers (Oliver, 1980). Negative brand experience leads to different behaviors. For instance, passive brand hate, which is caused by a negative experience, influences brand avoidance (Bayarassou et al., 2020). Negative experience occurs due to different reasons like dissatisfied offerings and product failures (Hashim \& Kasana, 2019). Recent research found that negative experience influences negative word of mouth and brand retaliation (Pinto \& Brandao, 2021).

\subsection{Brand Avoidance}

Brand avoidance has been defined as a phenomenon whereby consumers deliberately choose to keep away from or reject a brand (Lee et al., 2008, as cited in Lee et al., 2009b), except situations where brands are not purchased since brands are unaffordable, unavailable, or inaccessible (Lee et al., 2009a). The active rejection of brands includes the behaviors of giving up a brand that was previously consumed (abandonment), staying away or moving away from a brand (avoidance), and turning away from a brand (aversion), according to the explanation given by Hogg et al., (1998), as cited in Kavaliauske \& Simanaviciute (2015). From a consumer perspective, this may be because the brand does not meet the consumer's requirements and expectations (Liu, 2019). Lee et al. (2009a) pointed out four types of brand avoidance: experiential avoidance, deficit-value avoidance, identity avoidance, and moral avoidance. Later Knittel et al. (2016), as cited in Zouaoui (2019), added another type of brand avoidance called marketing communication avoidance.

\subsection{Negative Emotions}

Emotions can be defined as states that comprise feelings, psychological changes, expressive behavior, and inclinations to act (Frijda et al., 2000). Laros and Steenkamp (2005), as cited in Safana (2018), suggested negative emotions toward brands as consumers' negative emotional reactions aroused by evaluating the brand-related stimuli. 
Negative consumer emotions can be identified as anger, discontent, dislike, embarrassment, sadness, and worry (Romani et al., 2012). Consumers can experience various negative emotions to brands, even in the absence of purchase, such as responding to different marketing stimuli (Romani et al., 2008). However, when the brands fail to meet consumer expectations, consumers will feel stronger dislike and anger toward the brand (Kavaliauske \& Simanaviciute, 2015). The behavior of customers is driven by Emotions, and it is strongly related to loyalty (Razzaq et al., 2017). When different emotions and concepts from customers are analyzed, it allows prioritizing as well as mapping the customer relationship touchpoints (Pinto \& Brandao, 2021).

Figure 1: The conceptual model

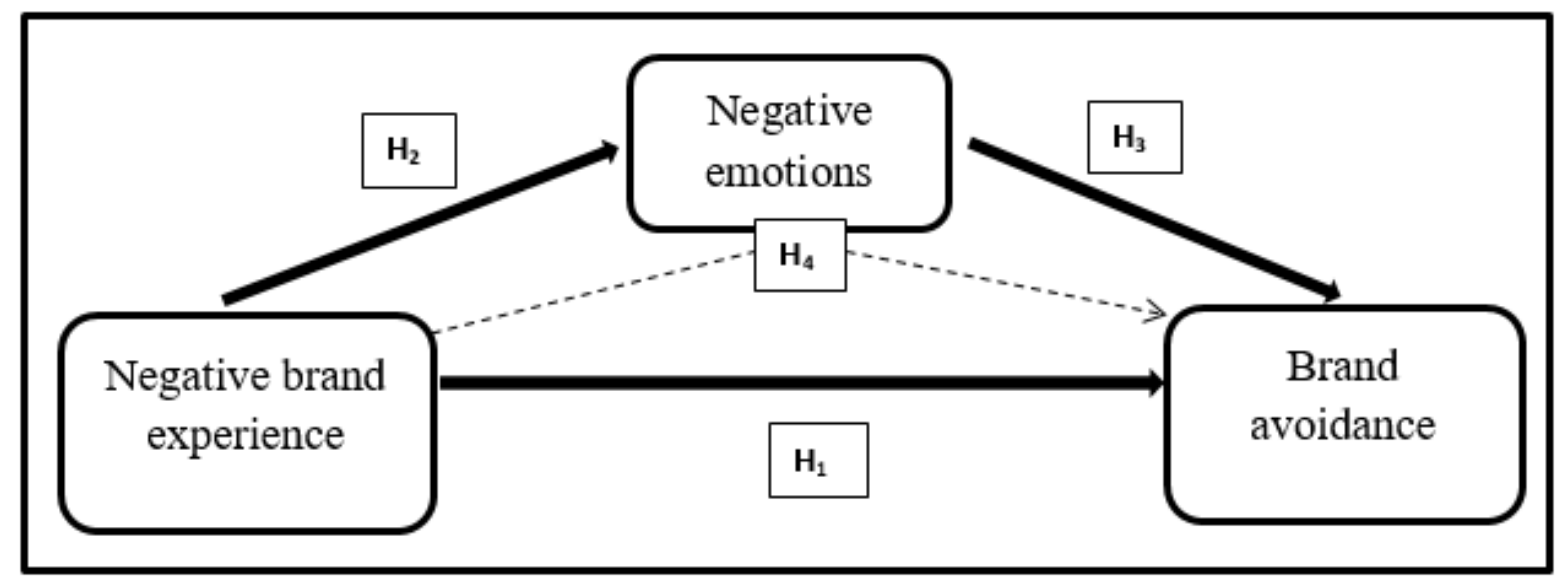

Source: Developed by the authors, 2021

\subsection{Influence of Negative Brand Experience on Brand Avoidance}

Lee et al. (2012, as cited in Kavaliauske \& Simanaviciute, 2015) mentioned that the previous negative experiences are the most important in anti-consumption behaviors. A bad consumer experience can eliminate any consumer's feelings about the brand and even make the brand disappear forever as far as they are concerned (Liu, 2019). Negative past experience with the product or service brand, corporate wrongdoing related to immoral, unethical, anti-social, or illegal corporate behavior, and incongruence between the company brand image and self-image are associated with various negative customer behavior outcomes (Zarantonello et al., 2018). Furthermore, negative word of mouth regarding a brand may be aroused when a consumer expresses unpleasant experiences to another consumer who may also avoid that brand in the future (Anderson, 1998, as cited in Hellberg et al., 2016). Among the fresh/ recent bad experience and repeated bad experiences, repeated bad experiences which can contribute to brand failure as a pattern in consumer's mind may easily generate emotions toward a desire for brand avoidance (Zhang, 2017). Many studies show that negative past experience is associated with various negative customer behavior outcomes (Zarantonello et al., 2018). Khan (2018) based on a study done using the only smartphone uses in Islamabad and Rawalpindi in Pakistan, has concluded that if 
consumers have negative past experiences for a brand, it leads to brand avoidance. Furthermore, negative word of mouth regarding a brand may be aroused when a consumer expresses unpleasant experiences to another consumer who may also avoid that brand in the future (Anderson, 1998, as cited in Hellberg et al., 2016).

The present study explores whether negative brand experience impacts brand avoidance in the mobile telecommunication services industry of Sri Lanka. Due to the complexity of selecting amongst thousands of similar offerings of telecommunication service providers, consumers will instinctively attempt to simplify their choice process, especially in low-involvement situations. Therefore, consumers heavily rely on previous consuming experiences (Gunawardane, 2015). Mobile service customers are sufficiently familiar with service providers, and therefore, they inform their brand choices and continued usage intention based on their past experience (Ojiaku \& Osarenkhoe, 2018). It indicates that negative brand experience could lead to brand avoidance in this industry.

However, negative brand experience may not always lead to brand avoidance due to some switching costs or situations as potential brand avoidance barriers such as lack of alternatives, the influence of others, inertia, and low product involvement (Lee et al., 2009, as cited in Kim et al., 2013). There are only a few mobile telecommunication service providers in the Sri Lankan market, indicating lack of alternatives in the mobile telecommunication services industry in Sri Lanka (Gunawardane, 2015), which is a condition under which the negative brand experience and brand avoidance relationship may not hold (Lee et al., 2009, as cited in Kim et al., 2013).

Further, rejecting a specific brand may be mediated by the marketing environment, the social environment, or the consumer's individual environment (Hogg et al., 2009 as cited in Strandvik et al., 2013). In a country where people have close family ties and strong social links, social factors influence consumer buying behavior (Tan \& Chua, 2007). Both normative and informational social influence can affect a decision maker's product evaluations (Burnkrant et al., Thomas, 1982). When considering the Sri Lankan context, it has an oriental culture where people are still strongly rooted in traditional cultural values and family ties, and these social influences in the form of friends and family's advice in buying behavior are dominant factors (Tan \& Chua, 2007). Therefore, previous findings regarding the relationship between negative brand experience and brand avoidance may not apply to the Sri Lankan consumer.

When considering all of these situations in the Sri Lankan context, it can be expected that the condition of the relationship between negative brand experience and brand avoidance in Sri Lanka may show a different finding compared to other contexts. Researches on brand avoidance among Sri Lankan consumers appear to be lacking, and no studies could be found on brand avoidance in Sri Lanka or the effects of negative brand experience. This background indicates a gap between negative brand 
experience and brand avoidance in the mobile telecommunication services industry in the Sri Lankan context.

Based on the findings of previous studies, the first hypothesis of this study proposes that;

$\mathbf{H}_{1}$ Negative brand experience has a positive impact on brand avoidance in the mobile telecommunication services industry in Sri Lanka.

\subsection{Influence of Negative Brand Experience on Negative Emotions}

It is evident that various negative emotions may arise due to negative brand experiences (Kavaliauske $\&$ Simanaviciute, 2015). Many studies have been done regarding negative emotions and their influence on negative behavior outcomes as brand avoidance. Various Unhappy marketing stimuli result in negative emotions (Romani et al., 2012). Berger and Milkman (2012) explained that high intense information and such arousal evoke negative and positive emotions. Scholars agree that emotions play a role in environmental events/ stimuli and behavioral reactions (Dalli et al., 2007, as cited in Kavaliauske \& Simanaviciute, 2015). When the brands fail to meet consumer expectations, consumers will feel stronger dislike, anger, and emotions toward the brand (Kavaliauske \& Simanaviciute, 2015). It can be clearly indicated that various negative emotions may arise due to negative brand experiences (Kavaliauske \& Simanaviciute, 2015). Based on these findings, this study proposes the following hypothesis;

$\mathbf{H}_{2}$ Negative brand experience has a positive impact on negative emotions in the mobile telecommunication services industry in Sri Lanka.

\subsection{Influence of Negative Emotions on Brand Avoidance}

Many studies have been done regarding negative emotions and their influence on negative behavior outcomes as brand avoidance. Scholars agree that emotions play a role in environmental events/stimuli and behavioral reactions (Dalli et al., 2007, as cited in Kavaliauske \& Simanaviciute, 2015). When the brands fail to meet consumer expectations, consumers will feel emotional toward the brand (Kavaliauske \& Simanaviciute, 2015). Specific negative emotions have direct effects on behavioral responses (Romani et al., 2008). Studies show that brand avoidance behavior appears when negative opinions about brands become so strong, and they can arouse negative emotions, which work as barriers to purchasing toward the brand (Romani et al., 2008). Based on these findings, this study proposes that;

$\mathbf{H}_{3}$ Negative emotions have a positive impact on brand avoidance in the mobile telecommunication services industry in Sri Lanka. 
2.8. Negative emotions as a mediator of the Relationship between Negative Brand Experience and Brand Avoidance

When consumers experience repeated product failures, it worsens their feelings toward the brand (Zarantonello et al., 2018). In the service industry, most dissatisfaction is directly linked with the quality of the service provider's work (Cho \& Song, 2012). Therefore, it can be expressed that various negative emotions may arise due to negative brand experiences (Kavaliauske \& Simanaviciute, 2015).

Negative relationships compared to positive ones are more problematic as negative outcomes are more memorable, more diagnostic, and evoke more important psychological responses (Fournier et al., 2013, as cited in Ramirez \& Merunka, 2019). Unwanted consumer behavior, including brand avoidance, can be caused by consumers' experiences of negative emotions toward the brand (Romani et al., 2009, as cited in Kavaliauske \& Simanaviciute, 2015). Brand avoidance happens when negative views about brands become so strong, and they can inspire negative emotions, which work as barriers to purchasing toward the brand (Romani et al., 2008).

Researchers have found that emotions mediate the relationship between brand-related stimulus and consumer behavior (Dalli et al., 2007, as cited in Kavaliauske \& Simanaviciute, 2015). Further, brand hate mediates the relationship between negative experience and brand avoidance (Pinto \& Brandao, 2021). When brands fail to meet customer expectations by their brand performance, it leads to developing negative emotions, and further, these negative emotions will result in brand avoidance (Khan, 2018). Based on these findings, this study proposes that;

$\mathbf{H}_{4}$ Negative emotions mediate the relationship between negative brand experience and brand avoidance in the mobile telecommunication services industry in Sri Lanka.

The conceptual model given in figure 1 was developed to show the relationships of the above-discussed hypotheses.

\section{METHODOLOGY}

This research was a positivistic study and used the survey strategy to collect the data.

The unit of analysis of this study was the individual mobile telecommunication consumers. According to GSMA (2013), mobile penetration is high in urban areas in Colombo, Gampaha, Kalutara, Kandy, and Galle. These are the most urbanized districts in Sri Lanka (Weeraratne, 2016). Therefore, mobile phone users in these cities were selected for the sample.

The age group between 16- 69 was considered in the data collection since any citizen who is 16 years of age can apply for the National Identity Card (The Government Information Center, n.d.), and anyone 
can get a SIM connection under his or her National Identity Card number (Telecommunications Regulatory Commission of Sri Lanka, n.d.).

The sample size selected was 120 respondents. It was decided by considering the minimum sample size required for structural equation models. For SEM models with five or fewer constructs, the required minimum sample size is 100 (Hair et al., 2010). The sample was selected using a convenience sampling method. The reason for using non-probability sampling was the various constraints that can arise in compiling an appropriate sampling frame. A five-point Likert scale was used in the questionnaire to collect the data. In operationalization, to measure the three latent constructs given in the model, ten indicator variables were selected from previous studies mentioned in the literature review. Accordingly, a negative brand experience construct was measured by three indicator variables. They were lack of employee-customer cooperation, frustration, and inconvenience (Liu, 2019; Lee et al., 2009b). Five indicator variables were used to measure the construct of negative emotions, and they were anger, dislike, fear, discontented, and awkwardness. These variables were used in studies done by Romani et al. (2008). Two indicator variables identified to measure the construct of brand avoidance were 'not buying' and 'not using.' as was done by Hegner et al. (2017).

The questionnaire was developed in two languages; English and Sinhala. The respondents were instructed to answer the questionnaire based on their current or used mobile telecommunication service provider. Confirmatory factor analysis and structural equation model were used to analyze the collected data with the help of SPSS and AMOS 23.

\subsection{Data Analysis}

At the beginning, multivariate assumptions were checked. The constructs and indicators used in this study were taken from previous research with careful adjustments wherever necessary in order to increase the validity and reliability of the measurements. However, validity and reliability were checked at the beginning, and unidimensionality was also checked by using CFA. The research applied structural Equation modeling (SEM) to test the causal and mediator relationships of constructs simultaneously.

\subsection{Multivariate Assumptions}

At the beginning of the data analysis, a test for multivariate assumptions was conducted. As depicted in Table 1, Skewness and kurtosis statistics were within the recommended range of +2 and -2 range. These results ensured the data were normally distributed and parametric tests can be applied. 
Table 1: Normality Test Results

\begin{tabular}{|c|c|c|c|c|c|c|c|}
\hline & \multirow{2}{*}{$\begin{array}{l}\mathrm{N} \\
\text { Statistic }\end{array}$} & \multirow{2}{*}{$\begin{array}{l}\text { Mean } \\
\text { Statistic }\end{array}$} & \multirow{2}{*}{$\begin{array}{l}\text { Std. } \\
\text { Deviation } \\
\text { Statistic }\end{array}$} & Skewness & \multicolumn{3}{|c|}{ Kurtosis } \\
\hline & & & & Statistic & Std. Error & Statistic & Std. Error \\
\hline Frustration & 120 & 2.6896 & .64861 & -.222 & .221 & .791 & .438 \\
\hline Lack_Coop & 120 & 2.7631 & .69506 & .557 & .221 & .502 & .438 \\
\hline Inconvenience & 120 & 2.7607 & .69670 & .521 & .221 & .244 & .438 \\
\hline Anger & 120 & 2.4083 & .92326 & .067 & .221 & -.570 & .438 \\
\hline Dislike & 120 & 2.0861 & .84404 & .061 & .221 & -1.313 & .438 \\
\hline Fear & 120 & 2.1806 & .87383 & .237 & .221 & -.721 & .438 \\
\hline Discontented & 120 & 2.4667 & .96377 & .309 & .221 & -.221 & .438 \\
\hline Awkwardness & 120 & 2.1056 & .86209 & .325 & .221 & -.617 & .438 \\
\hline Not_Buy & 120 & 2.4833 & .94464 & .302 & .221 & -.325 & .438 \\
\hline Not_Use & 120 & 2.4250 & .98657 & .406 & .221 & -.230 & .438 \\
\hline
\end{tabular}

\subsection{Test of Adequacy of Sample}

For testing sample adequacy, the Kaiser-Meyer-Olkin Measure of Sampling Adequacy test was conducted, and all values are greater than 0.5 as given in Table 2, ensuring the required sample adequacy (Kaiser,1974; Malhothra \& Dash, 2010). Therefore, factor analysis is appropriate for the data collected.

Bartlett's test of Sphericity is a recommended measure of multivariate normality of a set of a distribution. According to Field (2000), when the significant value is less than 0.05, the distribution is multivariate normal and acceptable for factor analysis. The values obtained in the present research are highly significant, and further analysis can proceed with CFA and SEM.

Table 2: KMO and Bartlett's Test of Sphericity

\begin{tabular}{llll}
\hline Construct & KMO & \multicolumn{2}{l}{ Bartlett's Test of Sphericity } \\
\hline & & Chi-Square & Sig. \\
Negative Brand Experience & 0.744 & 208.267 & 0.000 \\
Negative Emotions & 0.870 & 515.527 & 0.000 \\
Brand Avoidance & 0.500 & 198.930 & 0.000 \\
\hline
\end{tabular}

Source: Survey Data, 2021

\subsection{Confirmatory Factor Analysis (CFA)}

As the first step, a measurement model was developed, and a confirmatory factor analysis was done. 


\subsection{Model fit}

Table 3: Goodness of Fit Indices

\begin{tabular}{|l|l|l|l|l|l|l|l|l|l|l|l|}
\hline Criterion & CMIN & df & CMIN/df & GFI & CFI & RFI & PNFI & PCFI & IFI & TLI & RMSEA \\
\hline Values & 50.731 & 32 & 1.585 & 0.926 & 0.981 & 0.929 & 0.675 & 0.697 & 0.981 & 0.973 & 0.070 \\
\hline
\end{tabular}

CMIN: $\chi 2$; df: degrees of freedom; CMIN/df: Normed fit index; GFI: Goodness of fit index; CFI: Comparative fit index; RFI: Relative fix index; PNFI: Parsimony normed index; IFI: Incremental fit index; TLI: Tucker-Lewis Index; RMSEA: Root mean-square error of approximation

Source: Survey Data, 2021

The Estimated CFA model was assessed based on accepted scrutinizing model fit indices. The $\chi 2$ of the model was 50.731 with $p>0.05$ and 32 degrees of freedom, making Normed Fit index $=1.585$, which was within the acceptable region according to the criteria given by Holmes-Smith (2012), and Suki (2017). According to Hair et al. (2010), a GFI value over 0.90 is better, and therefore, the obtained value for GFI has reached the acceptable limit. With reference to the recommended values given by Suki (2017) and Parry (2020), the Comparative Fit Index was within the recommended levels. Parsimony Normed Index and Parsimony Comparative Fit Index were within the recommended levels according to the criteria given by Hair et al. (2010) and Suki (2017). Further, with reference to the criteria set by Hair et al. (2010), Suki (2017), and Holmes-Smith (2012), Incremental Fit Index and Relative Fix index were within the recommended levels. RMSEA or Root Mean Square Error of Approximation is well within the acceptable range (Hair et al., 2010). Tucker-Lewis Index is indicating a reasonable fit (Hair et al., 2010; Suki, 2017; Holmes-Smith, 2012). Therefore, as indicated by all these values, the proposed measurement model seems to fit these data well.

\subsection{Unidimensionality}

As shown in Table 4 and Figure 2, the factor loadings were well exceeding 0.5, and all of them were positive and significant $(\mathrm{P}<0.001)$. Therefore, the unidimensionality was confirmed as very high $(\mathrm{Cook}$ \& Kallen, 2009; Slocum-Gori, \& Zumbo, 2011).

Table 4: Standardized Factor Loading of Confirmatory Factor Analysis (CFA)

\begin{tabular}{|lll|c|}
\hline & & & Estimates*** \\
\hline Frustration & $<---$ & NegativeExperience & .852 \\
Lack of Cooperation & $<---$ & NegativeExperience & .891 \\
Inconvenience & $<---$ & NegativeExperience & .833 \\
Awkwardness & $<--$ & NegativeEmotions & .865 \\
Discontented & $<--$ & NegativeEmotions & .850 \\
Fear & $<--$ & NegativeEmotions & .887 \\
Dislike & $<---$ & NegativeEmotions & .909 \\
Anger & $<---$ & NegativeEmotions & .825 \\
Not Buying & $<---$ & BrandAvoidence & .918 \\
\hline
\end{tabular}




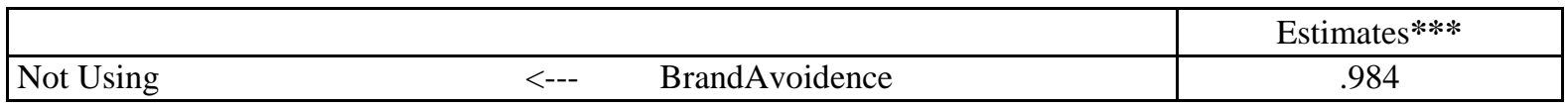

*** Statistically significant at .001

Source: Survey Data, 2021

Figure 2: Standardized Regression Weights of Confirmatory Factor Analysis (CFA)

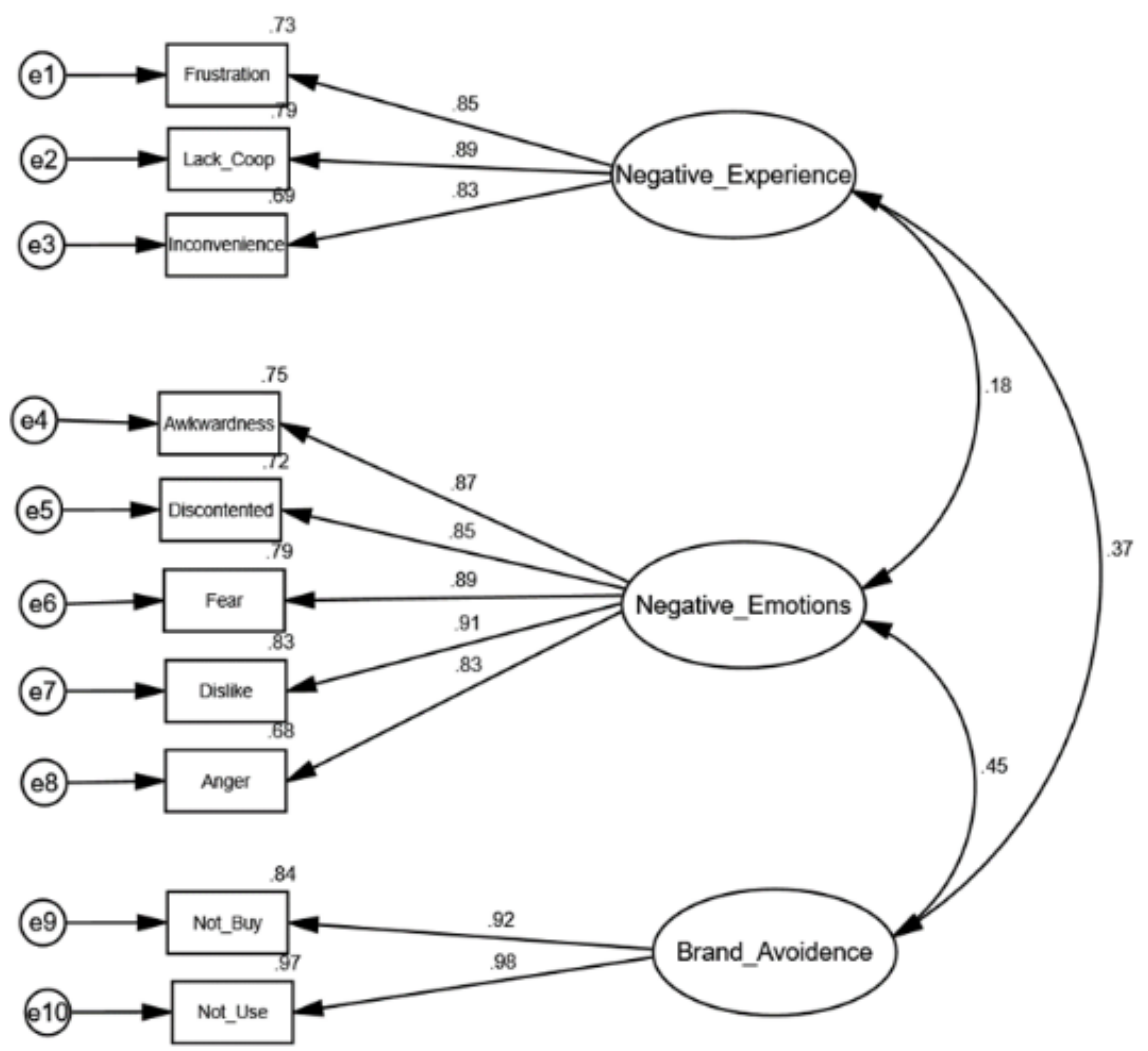

Source: Survey Data, 2021

\subsection{Reliability}

Cronbach's Alpha and Composite Reliability (CR) values given in Table 5 were used to assess the reliability of the measurement scales. As depicted in Table 5, Cronbach's alpha values were greater than 0.7 and thereby achieving the internal consistency for the scales used (Hair et al., 2010). CR values are also depicted in Table 5, and values greater than 0.7 are recommended for acceptable reliability (Fornell \& Larcker, 1981; Hair et al., 2010; Malhothra \& Dash, 2011). Accordingly, this model provides strong evidence for reliability. 
Table 5: Results of Reliability and Convergent Validity Tests

\begin{tabular}{|c|c|c|c|c|c|}
\hline Constructs & No. of Items & & $\begin{array}{l}\text { Cronbach's } \\
\text { Alpha }\end{array}$ & $\begin{array}{l}\text { Composite } \\
\text { Reliability } \\
\text { (CR) }\end{array}$ & $\begin{array}{l}\text { Average } \\
\text { Variance } \\
\text { Extracted } \\
\text { (AVE) }\end{array}$ \\
\hline $\begin{array}{l}\text { Negative Brand Experience } \\
\text { Frustration } \\
\text { Lack of Cooperation } \\
\text { Inconvenience }\end{array}$ & 3 & & 0.893 & 0.894 & 0.738 \\
\hline $\begin{array}{l}\text { Negative Emotions } \\
\text { Anger } \\
\text { Dislike } \\
\text { Fear } \\
\text { Discontented } \\
\text { Awkwardness }\end{array}$ & & 5 & 0.937 & 0.938 & 0.753 \\
\hline $\begin{array}{l}\text { Brand Avoidance } \\
\text { Not Buying } \\
\text { Not Using }\end{array}$ & & 2 & 0.949 & 0.950 & 0.905 \\
\hline
\end{tabular}

\subsection{Convergent Validity}

As depicted in Table 5, AVE values were above the recommended value of 0.5 , confirming the convergent validity was very high (Fornell \& Larcker, 1981; Hair et al., 2010).

\subsection{Discriminant Validity}

Table 6 shows the square roots of the AVE values given as bolded numbers on the principal diagonal are greater than the inter-construct correlations in their corresponding rows and columns. These results ensured the discriminant validity of the model (Fornell \& Larcker, 1981; Hair et al., 2010).

Table 6: Assessment of Discriminant validity

\begin{tabular}{llll}
\hline & Negative Brand Experience & Brand Avoidance & Negative Emotions \\
\hline Negative Brand Experience & $\mathbf{0 . 8 5 9}$ & & \\
Brand Avoidance & 0.369 & $\mathbf{0 . 9 5 1}$ & \\
Negative Emotions & 0.176 & 0.447 & $\mathbf{0 . 8 6 7}$ \\
\hline
\end{tabular}

Source: Survey Data, 2021

\subsection{Structural Model and Results}

A structural equation model was developed to test the causal relationships among latent constructs, and accordingly, hypotheses were tested. The model fit was examined using recommended goodness of fit indices. The indices were within the acceptable range. The $\chi 2$ of the model was 50.731 with $\mathrm{p}>0.05$, $\mathrm{CMIN} / \mathrm{df}=1.585 ; \mathrm{GFI}=0.926 ; \mathrm{CFI}=0.981 ; \mathrm{RFI}=0.929 ; \mathrm{PNFI}=0.675 ; \mathrm{PCFI}=0.697 ; \mathrm{IFI}=0.981$; $\mathrm{TLI}=0.973 ; \mathrm{RMSEA}=0.070$. Accordingly, these values ensured the postulated causal structure fit the data very well. 
Figure 3: Regression Weights of Structural Model

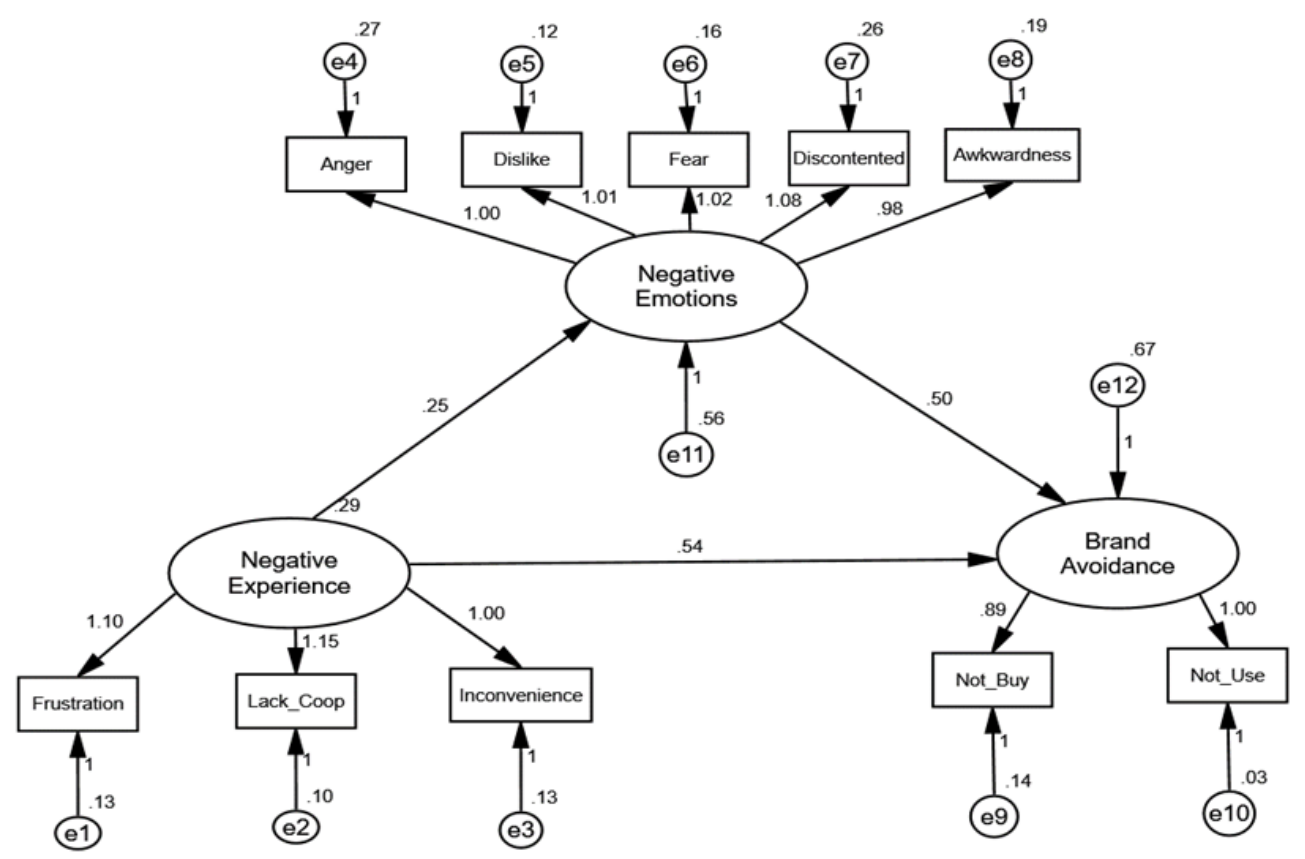

Source: Survey Data, 2021

Table 7: Regression Weights and Significance

\begin{tabular}{llll}
\hline & Paths & & Estimate \\
\hline Negative Experience & $------>$ & Negative Emotions & .249 \\
Negative Emotions & $------>$ & Brand Avoidance & $.503 * * *$ \\
Negative Experience & $------>$ & Brand Avoidance & $.539 * * *$ \\
\hline$* * *$ Statistically significant at 001 & &
\end{tabular}

*** Statistically significant at .001

Source: Survey Data, 2021

\subsection{Testing the Hypotheses}

As shown in Figure 3, the negative brand experience construct impacts brand avoidance positively, and the contribution is 0.54 . As depicted in Table 7, it is significant at the 0.001 level, and therefore, $\mathrm{H}_{1}$ can be accepted. The other latent construct, negative emotion, is also impacting positively, and it is contributing 0.50 at a significant level of 0.001 . Therefore, $\mathrm{H}_{2}$ is also accepted. The third hypostasis is about the impact of negative experience on negative emotions. It is not significant, and the contribution is also very low as 0.25 . Therefore, $\mathrm{H}_{3}$ is rejected. 
Table 8: Amalgamated Output Table of Direct Effects and Indirect Effects after Bootstrapping

\begin{tabular}{|c|c|c|c|c|c|c|}
\hline \multirow{3}{*}{$\begin{array}{l}\text { Latent } \\
\text { Constructs }\end{array}$} & \multicolumn{2}{|c|}{$\begin{array}{l}\text { Direct Effects } \\
\text { and } \\
\text { Two-Tailed Significance } \\
\text { Bootstrapping) }\end{array}$} & (BC) (after & \multicolumn{3}{|c|}{$\begin{array}{l}\text { Indirect Effects } \\
\text { and }\end{array}$} \\
\hline & Negative & Negative & Brand & Negative & Negative & Brand \\
\hline & Experience & Emotions & Avoidance & Experience & Emotions & Avoidance \\
\hline $\begin{array}{l}\text { Negative } \\
\text { Emotions }\end{array}$ & .249 & .000 & .000 & .000 & .000 & .000 \\
\hline $\begin{array}{l}\text { Brand } \\
\text { Avoidance }\end{array}$ & $.539 * * *$ & $.503 * * *$ & .000 & .125 & .000 & .000 \\
\hline
\end{tabular}

The fourth hypothesis was regarding the mediating role of negative emotions on the relationship between negative brand experience and brand avoidance. To test $\mathrm{H}_{4}$, the data depicted in Table 8 were used. According to Baron and Kenny (1986), for testing the mediation effect, there should be significant direct impacts from firstly independent variable to dependent variable, secondly from the independent variable to mediator variable, and thirdly from mediator variable to dependent variable. But in this present research, the impact of the independent variable on the mediator variable was not significant. Therefore, the first condition for mediation fails, and we cannot state with evidence that there is a mediation role played by negative emotions to the impact of negative brand experience on brand avoidance.

This conclusion can be confirmed by the bootstrapping (Preacher and Hayes, 2008) results, as depicted in table 8. Bootstrapping was done with 2000 iterations using the bias-corrected percentile method. Accordingly, the direct effects of both negative brand experience and negative emotions on brand avoidance were positive and significant at 0.001 levels. But the indirect effect of negative brand experience on brand avoidance through the mediator, i.e., negative emotions, was not significant and showing a very low effect as 0.125 . Therefore, the present research concludes that the $\mathrm{H}_{4}$, negative emotions mediate the relationship between negative brand experience and brand avoidance in the mobile telecommunication services industry of Sri Lanka is rejected.

Table 9: Summary of Hypothesis Testing

Hypotheses
Results

\begin{tabular}{cll}
\hline $\mathrm{H}_{1}$ & $\begin{array}{l}\text { Negative brand experience has a positive impact on brand avoidance in the mobile } \\
\text { telecommunication services industry of Sri Lanka. } \\
\mathrm{H}_{2}\end{array} \begin{array}{l}\text { Negative brand experience has a positive impact on negative emotions in the mobile } \\
\text { telecommunication services industry of Sri Lanka. } \\
\mathrm{H}_{3} \quad \begin{array}{l}\text { Negative emotions have a positive impact on brand avoidance in the mobile } \\
\text { telecommunication services industry of Sri Lanka. }\end{array}\end{array}$ & Supported \\
$\mathrm{H}_{4} \quad \begin{array}{l}\text { Negative emotions mediate the relationship between negative brand experience and } \\
\text { brand avoidance in the mobile telecommunication services industry of Sri Lanka }\end{array}$ & Not Supported \\
\hline
\end{tabular}




\section{FINDINGS AND DISCUSSION}

\subsection{Negative Brand Experience and Brand Avoidance}

This research found that negative experience has a significant positive impact of 0.54 (at 0.001 significant level) to brand avoidance in Sri Lankan mobile telecommunication market. This study provides insights into the knowledge of consumers' brand avoidance. The tendency in avoidance behavior is a threat to any business as the mobile telecommunication services businesses, especially the competition, are very severe since the number of competitors as well as the frequently upgrading technical knowhow. As this study mainly focused on the mobile telecommunication industry, the findings of this study will mainly contribute to the managerial decisions in the mobile telecommunication services businesses. Besides, Tosun et al. (2015) have stated past experience affects future behavior. The importance of core services and their different dimensions have been identified by different scholars in studies conducted in other countries (Mattila, 2004; Katara et al., 2008; Celik, 2019). A research done in Sweden and United States found that consumers' unpleasant experience affects negative word of mouth which in turn leads to brand avoidance (Anderson, 1998, as cited in Hellberg, Melander \& Vong, 2016). This finding is affirmed by this present study in the Sri Lankan context. Consumers' brand choices and usage intentions are based on past experience, as found by Ojiaku and Osarenkhoe (2018). This is a similar finding that goes with present research.

\subsection{Negative Brand Experience on Negative Emotions}

The impact of negative experiences on negative emotions is 0.25 and seemed to be very minimal. Further, it was not statistically significant. This implies that customers do not become emotional in Sri Lankan mobile telecommunication even though they have adverse experiences with their services. The rationale is that brand switching in mobile connection is very easy, and that can be done at a very low cost as some of the offers are concerned. As far as prepaid connections are concerned, a sim card is very cheap in the market, and they can be purchase another new brand conveniently from a communication center in proximity. It is evident that people use several sim cards at the same time. So discarding and purchasing a new sim is very convenient than getting emotional, blaming, and wasting time. If customers need different services like internet connections and other different packages with different deposit levels, people go to the service provider and negotiate. That experience in showrooms of service providers would affect these negative experiences and emotions. However, in other countries, experiences are different. For example, generally, in branding literature, Kavaliauske \& Simanaviciute (2015) have found that when brands fail to satisfy customers, they become emotional. Further, various negative emotions are expected to be arisen due to negative brand experiences (Kavaliauske \& Simanaviciute, 2015). Negative emotions are sometimes resulting from various unhappy marketing stimuli (Romani et al., 2012), which is also a kind of negative experience. The findings of the present 
research do not agree with that. Berger and Milkman (2012) pointed out that information in higher intensity and such arousal evokes emotions both negative and positive. But they did not study negative experiences that also cause negative emotions. Even though information flow endlessly as marketing communication, people seem to be not emotional in the Sri Lankan context.

\subsection{Negative Emotions on Brand Avoidance}

The impact of Negative emotions on brand avoidance has a significant and positive effect of 0.50 (significant at 0.001 level). This is also a new contribution to the body of knowledge in Sri Lankan literature, removing the theoretical gap that so far existed. Negative emotions were measured by anger, dislike, fear, discontent, and awkwardness, and they provide significant knowledge about how to fill the empirical gap in the Sri Lankan mobile telecommunication industry. Romani et al. (2008) has found that negative emotions have affected negative behaviors. This is consistent with the act that people who feel negative emotions about a brand tend to avoid purchasing it. According to Razzaq et al. (2017), customers' behavior is driven by emotions and leads to loyalty. The present finding also has similar observation, and researchers found that negative emotions affect brand avoidance. Because emotions have such influential ability, Pinto and Brandao (2021) suggested that analyzing the emotions will help to prioritize customers and to map the customer relationship touchpoints. Then, it will help to minimize brand avoidance.

\subsection{Mediating effect of negative emotions on the relationship between negative brand experience and brand avoidance}

The indirect effect of negative brand experience through negative emotions on brand avoidance was 0.125 , and it was not statistically significant as bootstrap results shows. Same time, the impact of negative brand experience on negative emotions is also not statistically significant.

Hence, this study is inconsistent with the previous findings in other countries that negative emotions mediate the relationship between negative brand experience and brand avoidance. For example, scholars have agreed that emotions are mediators between brand-related stimuli and behavioral responses (Dalli et al., 2007 as cited in Kavaliauske \& Simanaviciute, 2015). This study could not ensure that negative emotions can play as a mediator between negative experiences and negative behavioral outcomes as brand avoidance. Khan (2018) has found that when a brand fails to meet customers' expectations in some other countries, it leads to negative emotions and, consequently, results in brand avoidance. The present findings show that when customers get negative experiences, it directly affects brand avoidance rather than customers become emotional and in turn leading to brand avoidance. 


\section{CONCLUSION}

This research attempted to study whether negative brand experience impacts brand avoidance in the mobile telecommunication services industry of Sri Lanka. In addition, this study had other three objectives: identifying whether negative brand experience affects negative emotions, whether negative emotions affect brand avoidance, and whether negative emotions mediate the relationship between negative brand experience and brand avoidance.

According to the findings, firstly, it could be identified that negative brand experience positively impacts brand avoidance. Secondly, negative brand experience showed no significant effect on negative emotions. Thirdly, negative emotions' positive effect on brand avoidance could be identified from this study. Finally, as per the analysis, researchers could not find evidence to prove that the construct, negative emotion, is mediating the relationship between negative brand experience and brand avoidance.

As mentioned at the beginning, a theoretical gap existed due to a lack of comprehensive understanding and conflicting viewpoints regarding negative brand experience and brand avoidance. Present research shed light to remove this theoretical gap finding that both negative experiences, as well as negative emotions, affect brand avoidance. According to our understanding, this kind of research has not been done in the Sri Lankan context, and therefore, these findings bridge the theoretical gap that existed in Sri Lankan literature. Further, the empirical gap also filled by this research providing the practitioners about adverse repercussions of bad practices in their services.

\subsection{Theoretical and managerial Implications}

This research provides vital managerial implications to decision-makers in those businesses. They must use these insights to realize the impact of their service deficiencies with regard to negative experiences and negative emotions. Service firms must give attention to their core services and manage service employees effectively to keep employee-customer cooperation. So, managers can use these findings to retain their customers before they go to the avoidance stage. This study encourages managers to find effective ways to manage avoidance behaviors while carefully concerning customers' emotions. In a nutshell, it can be emphasized that negative brand experience and negative emotions cannot be easily neglected in managerial decision-making since both are vital in causing brand avoidance.

Decision-makers must be careful in designing and offering the services since failure to look after certain aspects may adversely affect the business. For example, deficiencies in core service such as not providing suitable service, less reliability, less quality offered, lack of variety of offers, and inconsistent services need immediate amendments. Regarding employee behavior, inability to provide prompt service, unwillingness to help, not trustworthiness of employees, not providing safe service, less 
politeness, and lack of personal attention to their customers are worthy of being re-considered and make necessary adjustments in future operations. As to services cape, the incapability of acquiring state-ofthe-art technology and providing an attractive, suitable service facility or atmosphere is critical and needs immediate attention. Further, neat service facilities, less crowded offices, convenient arrangements, and comfortable waiting facilities should be introduced and maintained. Incapability to fulfill these kinds of provisions by mobile service providers will lead customers to a negative brand experience, affecting brand avoidance.

\subsection{Limitations and Future Research}

The present research focused on the impact of negative brand experience and negative emotions on brand avoidance. Brand hate is another significant construct that affects brand avoidance, but present research did not consider it. Therefore, it can be incorporated into a similar study simultaneously with the same constructs. Further, this research found that customers are not becoming emotional even though the customers get negative experiences. However, in some other countries, they become emotional in such situations. This needs further research to understand how country-specific factors influential in consumer behavior with regard to brand avoidance.

\section{REFERENCES}

Anderson, E.W. (1998). Customer satisfaction and word of mouth. Journal of Service Research, 1 (1), 5-7

Asia Pacific region owned the largest unique mobile subscribers number 2017/ GSMA. (n.d.). Retrieved 07 012021 from https://www.digitalmarketingcommunity.com/indicators/asia-pacific-always-regionlargest-unique-internet-subscribers-number-q1-2017-gsma/

Baron, R. M. \& Kenny, D. A. (1986). The moderator- Mediator variable distinction in social psychological research: Conceptual, strategic, and statistical considerations. Journal of personality and social psychology, 51(6), 1173- 1182.

Baumeister, R., Bratslavsky, E., Finkenauer, C., \& Vohs, K. (2001). Bad is stronger than good. Review of General Psychology, 5, 323-370. https://doi.org/10.1037/1089-2680.5.4.323

Bayarassou, O., Becheur, I., \& Vallete-Florence, P. (2020). "Fight or flight": coping responses to brand hate. Journal of Product \& Brand Management, https://doi 10.1108/JPBM-08-2019-2519

Berger, J. \& Milkman, K. L. (2012). What makes online content viral? Journal of Marketing Research, 49 (2), 192-205.

Celik, O. (2019). The effect of the store servicescape on the customers regarding the telecommunication sector. Journal of Academic Researches and Studies, 11(21), 577-590.

Central Bank of Sri Lanka (2018). Economic and social statistics of Sri Lanka. Retrieved from https://www.cbsl.gov.lk/sites/default/files/cbslweb_documents/statistics/otherpub/economic_and_socia 1_statistics_of_SL_2018_e_0.pdf

Chen, F., Curran, P. J., Bollen, K. A., Kirby, J. \& Paxton, P. (2008). An empirical evaluation of the use of fixed cut-off points in RMSEA test statistic in structural equation models. Sociological Methods and Research,36 (4), 462-494. https://doi: 10.1177/0049124108314720 
Cho, Y. C. \& Song, J. (2012). The effects of customer dissatisfaction on switching behavior in the service sector. Journal of Business \& Economics Research, 10(10), 579-592. Retrieved 07012021 from https://doi.org/10.19030/jber.v10i10.7267

Coltman, T., Devinney, T. M., Midgley, D. F. \& Venaik, S. (2008). Formative versus reflective measurement models: Two applications of formative measurement. Research Online, University of Wollongong. https://ro.uow.edu.au/infopapers/689

Cook, K.F. \& Kallen, M.S. (2009). Having a fit: Impact of number of items and distribution of data on traditional criteria for assessing IRT's unidimensionality assumption. Quality of Life Research, 18(4), 447-460

Datareportal (2021). Mobile connections in Sri Lanka. Retrieved $07 \quad 01 \quad 2021$ from https://datareportal.com/reports/digital-2021-sri-lanka

Dimitriadis, S., \& Koritos, C. (2014). Core service versus relational benefits: what matters most? The Service Industries Journal, $34 \quad$ (13), 1092-1112. $\quad$ Retrieved $07 \quad 01 \quad 2021$ from https://doi.org/10.1080/02642069.2014.939642

Dissanayake, D.M.R. (2010). Service failures and customer switching behavior of mobile communication services. IMS Manthan, $\mathrm{V}(2), \quad$ Retrieved $07 \quad 01 \quad 2021$ from https://www.researchgate.net/publication/278121920_Service_Failures_and_Customer_Switching_Beh avior_of_Mobile_Communication_Services_A_Study_of_Mobile_Communication_Service_Sector_of _Sri_Lanka

Field, A. (2000). Discovering statistics using SPSS for windows. London - Thousand Oaks - New Delhi: Sage publications.

Fornell, C \& Larcker, D. F. (1981). Evaluating structural equation models with unobservable variables and measurement error. Journal of Marketing Research, 18(1), 39-50.

https://doi.org/10.1177/002224378101800104

Frijda, N. H., Manstead, A. S., \& Bem, S. (2000). The influence of emotions on beliefs. Emotions and beliefs: How feelings influence thoughts, 1-9. Paris: Cambridge University Press. https://doi:10.1017/CBO9780511659904.001

Global System for Mobile Communications Association (GSMA), (2013). Analysis- Country Overview: Sri Lanka. Retrieved $07 \quad 012021$ from https:/www.gsma.com/mobilefordevelopment/wpcontent/uploads/2016/02/Country_Overview_Sri_Lanka.pdf

Global System for Mobile Communications Association (GSMA). (2019) Representing the worldwide mobile telecommunications industry. Retrieved 03012021 from https://www.gsma.com/

Gunawardane, N. R. (2015). Impact of brand equity towards purchasing decision: a situation on mobile telecommunication services of Sri Lanka. Journal of marketing management, 3(1), 100-117. https://doi: 10.15640/jmm.v3n1a10

Hair, J. F., Black, W.C., Babin, B.J., \& Anderson, R.E. (2010). Multivariate data analysis (7th Edition), Pearson Education, Inc.

Hashim, S., \& Kasana, S. (2019). Antecedents of brand hate in the fast food industry. Spanish Journal of Marketing 23 (2), 227-248. https://doi: 10.1108/SJME-10-2018-0047

Hegner, S. M., Fetscherin, M., \& van Delzen, M. (2017). Determinants and outcomes of brand hate. Journal of Product \& Brand Management, 26(1), 13-25. https://doi: 10.1108/JPBM-01-2016-1070 
Holmes-Smith, P. (2012). Structural equation modeling (using AMOS): From the fundamentals to advanced topics. Victoria: School Research Evaluation and Measurement Services.

Hussein, A. S. (2018). Effects of brand experience on brand loyalty in Indonesian casual dining restaurant: Roles of customer satisfaction and brand of origin. Tourism and hospitality management, 24(1), 119132. Retrieved from https://doi.org/10.20867/thm.24.1.4

Imbug, N., Ambad, S. N. A., \& Bujang, I. (2018). The influence of customer experience on customer loyalty in the telecommunication industry. International Journal of Academic Research in Business and Social Sciences, 8(3), 103-116. https:// doi: 10.6007/IJARBSS/v8-i3/3909

Johnston, R. (1995). The zone of tolerance: exploring the relationship between service transactions and satisfaction with the overall service. International Journal of Service Industry Management, 6(2), 46-61. $\begin{array}{lllll}\text { Retrieved } & 07 & 01 & 2021 & \text { from }\end{array}$ https://www.emerald.com/insight/content/doi/10.1108/09564239510084941/full/html?fullSc=1

Kiefer, T. (2005). Feeling bad: antecedents and consequences of negative emotions in ongoing change. Journal of Organizational Behavior. 26, 875-897 . https://doi: I: 10.1002/job.339

Kaiser, H. (1974). An index of factorial simplicity. Psychometrika, 39, 31-6.

Kanouse, D., Hanson, L. (1972). Negativity in evaluations. APA PsycNet , 47-62.

Kanouse, D. (1984). Explaining negativity biases in evaluation and choice behavior: Theory and research. Advances in Consumer Research, 11, 703-708

Kattara, H. S., Weheba, D., \& El-Said, O. A. (2008). The impact of employee behaviour on customers' service quality perceptions and overall satisfaction. Tourism and Hospitality Research, 8(4), 309-323. https:// doi: $10.1057 /$ thr.2008.35

Kavaliauskè, M., \& Simanavičiūtė, E. (2015). Brand avoidance: relations between brand-related stimuli and negative emotions. Organizations and markets in emerging economies, 6(1), 44-77. https://doi: 10.15388/omee.2015.6.1.14227

Khan, E.A., Dewan, M.N.A., \& Chowdhury, M.M.H. (2016). Reflective or formative measurement model of sustainability factor? A three industry comparison. Corporate Ownership and Control Journal, 13(2), 83-92

Khan, S. I. (2018). Impact of Product-Level Factors (Negative Past Experience, Unmet Expectations, and Perceived Deception) on Brand Avoidance and the Mediating Role of Brand Hate. J Account Mark, 7(306), 2. https://doi: 10.4172/2168-9601.1000306

Kim, H., Jung Choo, H., \& Yoon, N. (2013). The motivational drivers of fast fashion avoidance. Journal of Fashion Marketing and Management: An International Journal,17(2), 243-260. http://doi: 10.1108/JFMM-10-2011-0070

Knittel, Z., Beurer, K., \& Berndt, A. (2016). Brand avoidance among generation Y consumers. Qualitative Market Research: An International Journal, 19(1), 27-43. http://doi 10.1108/QMR-03-2015-0019

Kumaresh, R. (2009). Determinants of customer switching behavior in the telecommunication industry- Sri Lankan context [Doctoral dissertation, Moratuwa University]. Retrieved 07012021 from http://dl.lib.mrt.ac.lk/handle/123/965

Lee, M. S., Conroy, D., \& Motion, J. (2009b). Brand avoidance: a negative promises perspective. ACR North $\begin{array}{llllll}\text { American } & \text { Advances. } & \text { Retrieved } & 01 & 01 & 2021\end{array}$ http://www.acrwebsite.org/volumes/14318/volumes/v36/NA-36

Lee, M. S., Motion, J., \& Conroy, D. (2009a). Anti-consumption and brand avoidance. Journal of Business Research, 62(2), 169-180. http://doi: 10.1016/j.jbusres.2008.01.024 
Leung, L. C. (2016). The role of consumer-brand experiences and relationships in contributing to brand equity for services. Athens Journal of Business \& Economics, 2(2), 195-216. http://doi=10.30958/ajbe.2-2-6

Liu, X. (2019). Understanding Brand Avoidance Among Female Chinese Consumers: The driving forces behind negative consumption among female Chinese consumers. Retrieved 01012021 from http://urn.kb.se/resolve?urn=urn:nbn:se:hj:diva-44579

Malhotra, N. K., \& Dash, S. (2011). Marketing Research an Applied Orientation $6^{\text {th }}{ }^{\text {Edition}) ~ L o n d o n: ~ P e a r s o n ~}$ Publishing.

Mattila, A. S. (2004). The impact of service failures on customer loyalty: The moderating role of affective commitment. International Journal of Service Industry Management, 15(2), 134-149. http://doi: 10.1108/09564230410532475

Mohamad, M., Afthanorhan, A., Awang, Z. \& Mohammad, M. (2019). Comparison between CB-SEM and PLS-SEM: testing and confirming the Maqasid Syariah Quality of Life Measurement Model. The Journal of Social Sciences Research,5 (3), 608-614

Nenycz-Thiel, M., Romaniuk, J. (2011). The nature and incidence of private label rejection. Australasian Marketing Journal, 19, 93-99.

Odoom, R., Kosiba, J.P., Djamgbah, C.T. \& Narh, L. (2019). Brand avoidance: underlying protocols and a practical scale. Journal of Product \& Brand Management, 28 (5), 586-597. http://doi: 10.1108/JPBM03-2018-1777

Ojiaku, O. C., \& Osarenkhoe, A. (2018). Determinants of customers' brand choice and continuance intentions with mobile data service provider: The role of past experience. Global Business Review, 19(6), 14781493. Retrieved 01012021 from https://doi.org/10.1177\%2F0972150918780764

Oliver, R.L. (1980). A cognitive model of the antecedents and consequences of satisfaction decisions. Journal of Marketing Research, 17, 460-469.

Parry, S (2020). Fit indices commonly reported for CFA and SEM. Retrieved 01012021 from httpswww.cscu.cornell.edunewsHandoutsSEM_fit.pdf

Pinto, O. \& Brandao, A. (2021). Antecedents and consequences of brand hate: empirical evidence from the telecommunication industry. European Journal of Management and Business Economics, 30 (1), 18-35 http://doi: 10.1108/EJMBE-04-2020-0084

Preacher, K.J. \& Hayes, A.F.(2008). Asymptotic and resampling strategies for assessing and comparing indirect effects in multiple mediator models. Behavior Research Methods, 40 (3), 879-891. http://doi: 10.3758/BRM.40.3.879

Ramirez, R., \& Merunka, D. (2019). Brand experience effects on brand attachment: The role of brand trust, age, and income. http://doi: 10.1108/JPBM-09-2013-0392. Retrieved 07012021 from https://www.researchgate.net/publication/328043553

Razzaq, Z., Yousaf, S., \& Hong, Z. (2017). The moderating impact of emotions on customer equity drivers and loyalty intentions: Evidence of within sector differences. Asia Pacific Journal of Marketing and Logistics, 29(2), 239-264. https://doi: 10.1108/APJML-03-2016-0053

Rindell, A., Strandvik, T., \& Wilén, K. (2014). Ethical consumers' brand avoidance. Journal of Product \& Brand Management, 22 (7) 484-490.https://doi: 10.1108/JPBM-09-2013-0392.

Romani, S., Grappi, S., \& Dalli, D. (2008, November). I feel uneasy with this brand! Consumers' negative emotions to brands and behavioral responses. Proceedings of the 1st International Consumption and Consumer Resistance Conference, 28. 01-27 Retrieved $01 \quad 01 \quad 2021$ from 
https://www.academia.edu/download/42082212/I_feel_unease_with_this_brand_Consumers2016020430257-5i2cct.pdf

Romani, S., Grappi, S., \& Dalli, D. (2012). Emotions that drive consumers away from brands: Measuring negative emotions toward brands and their behavioral effects. International Journal of Research in Marketing, 29(1), 55-67. https://doi: 10.1016/j.ijresmar.2011.07.001

Safana, F. A. (2018). Brand avoidance: an insight from Ghanaian service consumers (Doctoral dissertation, Ghana University). Retrieved 12122021 from http://ugspace.ug.edu.gh/handle/123456789/30910

Schultz, J. (2017). The antecedents and outcome of service brand avoidance in the cell phone network service provider industry (Doctoral dissertation, Johannesburg University). Retrieved 07012021 from https://ujcontent.uj.ac.za/vital/access/services/Download/uj:28917/SOURCE1

Slocum-Gori, S.L. \& Zumbo, B.D. (2011). Assessing the unidimensionality of psychological scales: Using multiple criteria from factor analysis. Social Indicators Research, 102(3), 443-461

Suki, N.M., (2017) Green products usage: structural relationships on customer satisfaction and loyalty. International Journal of Sustainable Development \& World Ecology, 24(1), 88-95, https://doi: 10.1080/13504509.2016.1169563

Telecommunications Regulatory Commission of Sri Lanka. (n.d.). About your SIM. Retrieved 02012021 from http://www.trc.gov.lk/component/k2/item/126-about-your-sim.html\#home4

The Government Information Center. (n.d.). Obtaining a new Identity Card. Retrieved 01012021 from http://www.gic.gov.lk/gic/index.php/en/component/info/?id=416\&task=info

Thomas, R. J. (1982). Correlates of interpersonal purchase influence in organizations. Journal of consumer research, 9(2), 171-182. Retrieved from https://doi.org/10.1086/208910

Tiong Tan, C., \& Chua, C. (1986). Intention, attitude and social influence in bank selection: a study in an oriental culture. International Journal of Bank Marketing,4(3), 43-53. Retrieved from https://doi.org/10.1108/eb010783

Tosun, C., Dedeoğlu, B. B., \& Fyall, A. (2015). Destination service quality, affective image and revisit intention: The moderating role of past experience. Journal of Destination Marketing \& Management, 4(4), 222-234. https://doi.org/10.1016/j.jdmm.2015.08.002

TRCSL (2020). Telecommunication Regulatory Commission of Sri Lanka Report, Retrieved 14032021 from: http://www.trc.gov.lk/images/pdf/SOV_Q42020.pdf

Vong, A., Hellberg, A., \& Melander, J. (2016). Why do consumers avoid certain brands?: A study of brand avoidance within the Swedish cosmetics industry. Retrieved $3012 \quad 2020$ from http://urn.kb.se/resolve?urn=urn:nbn:se:hj:diva-30328

Weeraratne, B. (2016). Re-defining urban areas in Sri Lanka. (Working paper series, Institute of Policy Studies of Sri Lanka). (23), 3. Retrieved 23122020 from http://www.ips.lk/wpcontent/uploads/2017/01/Redefining-Urban-Areas.pdf

Wu, J., Qin, Y., \& Jia, F. (2018). Why do consumers hate brands? A conceptual paper of the determinants of brand hate. Proceedings of International Scientific Conference of Business Economics Management and Marketing, Brno: Masaryk University, 232-238. Retrieved $08 \quad 012021$ from https://webcentrum.muni.cz/media/3148134/iscobemm-2018-proceedings.pdf\#page=239

Zarantonello, L., Romani, S., Grappi, S., \& Bagozzi, R.P (2016). Brand hate. Journal of Product \& Brand Management 25 (1) 11-25. https://doi: 10.1108/JPBM-01-2015-0799 
Zarantonello, L., Romani, S., Grappi, S., \& Fetscherin, M. (2018). Trajectories of brand hate. Journal of Brand Management, 25(6), 549-560. https://doi: 10.1057/s41262-018-0105-5

Zhang, C. (2017). Brand Hate. (Doctoral dissertation, Concordia University). Retrieved 04012021 from https://spectrum.library.concordia.ca/982688/

Zouaoui, A. (2019). Brand Avoidance: An exploratory study on generation X within the airline industry. Retrieved 04012021 from http://urn.kb.se/resolve?urn=urn:nbn:se:hj:diva-44397</div> 